九州大学学術情報リポジトリ

Kyushu University Institutional Repository

\title{
Rainfall Prediction and Water Demand: Referring to the Thailand Gravity Irrigation District (6)
}

Fukuda, Tetsuro

Faculty of Agriculture, Gradute School, Kyushu University

https://doi.org/10.5109/4700

出版情報：九州大学大学院農学研究院紀要. 50 (2)，pp.917-926，2005-10-01. Faculty of Agriculture, Kyushu University バージョン：

権利関係 : 


\title{
Rainfall Prediction and Water Demand -Referring to the Thailand Gravity Irrigation District (6)-
}

\section{Tetsuro FUKUDA*}

\author{
Laboratory of Irrigation and Water Utilization, Division of Regional Environment Science, \\ Department of Bioproduction Environmental Sciences, Faculty of Agriculture, \\ Graduate School, Kyushu University, Fukuoka 812-8581, Japan \\ (Received July 25, 2005 and accepted July 26, 2005)
}

\begin{abstract}
In this paper, the probability of the rainfall was expressed in the Markoff's model, and the probability distribution was simulated by the Monte Carlo method, and the rainfall was generated simulatively. Using the rainfall in optional return period within generated rainfall, water demand was predicted. As the result, the relation between water demand and planting area in the dry season became clear. This fact becomes information which will be very precious in the water management in this area in future.
\end{abstract}

\section{INTRODUCTION}

The prediction of planting pattern, consumptive water use and rainfall is indispensable to the prediction of water demand. I replaced the planting pattern with the simple trapezoid in the previous report (T. Fukuda, 2005), and the basic factor which constituted the trapezoid was clarified. Then, the method for simply calculating planting area from the basic factor was developed. As the result, the prediction of future planting area became also possible.

And, evapotranspiration data for the past of 9 years was analyzed, and it was clarified that the annual range was very small. Therefore, there is no problem in using the monthly mean value for the evapotranspiration.

In this paper, the prediction of the rainfall should be tried. Usually, the rainfall is characterized by probability of the rainfall phenomenon and probability distribution of the rainfall. Then, it is possible to generate the rainfall simulatively, if the probability of the rainfall is expressed in the Markoff's model, and the probability distribution can be simulated by the Monte Carlo method.

It is possible to quantitatively reproduce the rainfall phenomenon with the uncertainty by the technique of the superscription including the phenomenon which can rarely generate in long duration, if features of transition probability of the rainfall generation and probability distribution of the rainfall are obtained from the rainfall series data in a past in the object area.

\section{PROBABILITY OF THE RAINFALL PHENOMENON}

The probability of the rainfall is expressed by the Markoff's process. The Markoff's

\footnotetext{
* Corresponding author (E-mail: tfukuda@bpes.kyushu-u.ac.jp)
} 
process is time series stochastic process without the memory, and it is the process in which the system changes to next condition only by present condition with some transition probability in spite of the phenomenon in a past. We try to express the probability of fine or rain by the application of the Markoff's process.

To begin with, the day in which for example, there is the rainfall over $1 \mathrm{~mm}$ is considered rainy weather day $(W)$, and the day under $1 \mathrm{~mm}$ is considered sunny day $(D)$. Next, the period is divided at the unit in a few days, and probability $P_{\mathrm{i}}(D D)$ in which the previous day is fine even in the day fine in the $\mathrm{i}^{\text {th }}$ period is calculated according to the following equation.

$$
P_{i}(D \mid D)=N_{i}(D \mid D) / N D_{i}
$$

Where $N_{\mathrm{i}}(D \mid D)$ is the days in which the previous day is fine even in the day fine, $N D_{\mathrm{i}}$ is the days in which the previous day is fine regardless of the weather in the day.

In the same way, probability $P_{\mathrm{i}}(W \mid W)$ in which the previous day is rain even in the day rain is calculated.

$$
P_{i}(W \mid W)=N_{i}(W \mid W) / N D_{i}
$$

Where $N_{\mathrm{i}}(W W)$ is the days in which the previous day is rain even in the day rain, $N D_{\mathrm{i}}$ is the days in which the previous day is rain regardless of the weather in the day.

Table 1(a) and Table 1(b) are examples of monthly transition probability of sunny day or rainy day, using daily rainfall data of the past 30-40 years in Sam Chuk and Ban Phraek respectively.

In this table, AV is expectation in each month, and SD is standard deviation in the month.

Table 1. (a) Example of transition probability in Sam Chuk

\begin{tabular}{rcccc}
\hline 月 & (DID) & $\mathrm{P}(\mathrm{W} I \mathrm{~W})$ & $\mathrm{AV}$ & $\mathrm{SD}$ \\
\hline 1 & 0.996 & 0.200 & 17.6 & 18.72 \\
2 & 0.975 & 0.136 & 18.4 & 22.56 \\
3 & 0.974 & 0.167 & 22.8 & 23.18 \\
4 & 0.928 & 0.115 & 18.2 & 22.29 \\
5 & 0.822 & 0.364 & 17.6 & 18.85 \\
6 & 0.803 & 0.363 & 14.1 & 14.90 \\
7 & 0.762 & 0.377 & 13.0 & 15.78 \\
8 & 0.755 & 0.458 & 15.6 & 16.75 \\
9 & 0.638 & 0.593 & 19.6 & 20.18 \\
10 & 0.817 & 0.448 & 20.5 & 20.15 \\
11 & 0.962 & 0.373 & 15.7 & 17.50 \\
12 & 0.990 & 0.000 & 7.7 & 5.08 \\
\hline
\end{tabular}

Table 1. (b) Example of transition probability in Ban Phraek

\begin{tabular}{rccrc}
\hline 月 & (DID) & P(WIW & AV & SD \\
\hline 1 & 0.988 & 0.235 & 18.2 & 23.82 \\
2 & 0.972 & 0.275 & 10.5 & 11.63 \\
3 & 0.947 & 0.129 & 13.9 & 18.22 \\
4 & 0.882 & 0.351 & 14.2 & 17.24 \\
5 & 0.742 & 0.440 & 17.5 & 19.48 \\
6 & 0.726 & 0.408 & 14.5 & 16.32 \\
7 & 0.728 & 0.419 & 13.6 & 14.36 \\
8 & 0.699 & 0.454 & 12.8 & 14.34 \\
9 & 0.643 & 0.593 & 18.9 & 20.13 \\
10 & 0.830 & 0.486 & 18.3 & 21.94 \\
11 & 0.941 & 0.337 & 12.3 & 12.08 \\
12 & 0.986 & 0.250 & 9.2 & 9.42 \\
\hline
\end{tabular}




\section{PROBABILITY DISTRIBUTION OF RAINFALL}

As a probability distribution of the rainfall, various statistical distribution are considered. In this paper, logarithmic normal distribution is adopted, and the distribution in proportion to every month is used. Table 1 shows expectation and standard deviation of the daily rainfall of monthly in Sam Chuk and Ban Phraek. The probability density function of logarithmic normal distribution is defined in following equation.

$$
f_{x}(x)=\frac{1}{\sqrt{2 \pi} \zeta_{x}} \exp \left(-\frac{(\ln (x)-\lambda)^{2}}{2 \zeta^{2}}\right), \quad(0<x<\infty)
$$

Where $x$ is a random variable, $\lambda$ is monthly logarithmic mean value of the observation rainfall, $\zeta$ is monthly logarithm standard deviation of the observation rainfall.

In addition, it is possible to calculate $\lambda$ and $\zeta$ from monthly expectation value $\sigma$ and monthly standard deviation $\mu$ of above-mentioned rainfall each according to the following equation.

$$
\begin{aligned}
& \zeta=\sqrt{\ln \left(1+\frac{\sigma^{2}}{\mu^{2}}\right)} \\
& \lambda=\ln (\mu)-\frac{1}{2} \zeta^{2}
\end{aligned}
$$

\section{SIMULATED GENERATION OF THE RAINFALL}

There are two processes in the simulated generation of the rainfall. In the first process, the persistence of the rainfall is expressed by the Markoff's process, and to begin with, sunny day or rainy weather day are decided. Next, the probability distribution of rainfall is considered logarithmic normal distribution, and the rainfall is generated with this logarithmic normal distribution in case of the rainy weather day simulatively. The concrete calculation method is as follows.

(1) The random number between $0 \sim 1$ is generated.

(2) Rain or fine are decided according to the random numbers and the transition probability matrix (refer to Table 1) of the rainfall beforehand required. In this case, the probability of rain or fine in the day is different by rain or fine in the previous day.

(3) When the day is rain, rainfall is generated according to the logarithmic normal distribution beforehand required.

It is based for next procedure for obtaining the normal random number by the computer. Mean value $m$ of the uniform random number of the $(0,1)$ interval is $1 / 2$, and variance $s^{2}$ is $1 / 12$. $u$ becomes a random number of standard normal distribution $(0,1)$ by the theorem of central limit value, if $u$ is calculated according to following equation, by adding random number $x_{\mathrm{i}}$ in order in the each $N$ piece. 


$$
u=\frac{\sum x_{i}-N / 2}{\sqrt{N / 12}}
$$

Using this $u$, random number $y$ of the random variable with normal distribution $\left(m, s^{2}\right)$ is obtained as $y=m+s \cdot u$. In case of the logarithmic normal distribution, random number is obtained by $z=\exp (y)$, because it is $\ln (z)=y$.

I made the program which can generate the daily rainfall for 100 years simulatively. The year has be made to be expedient 2001 2100. By trying the simulation of water demand quantity using the rainfall of various probability year obtained by this program, it is possible to estimate water demand pattern in proportion to various rainfalls patterns.

\section{PROBABILITY DISTRIBUTION OF ANNUAL RAINFALL}

Fig. 1(a) shows non-excess probability distribution of annual rainfall for 30 years

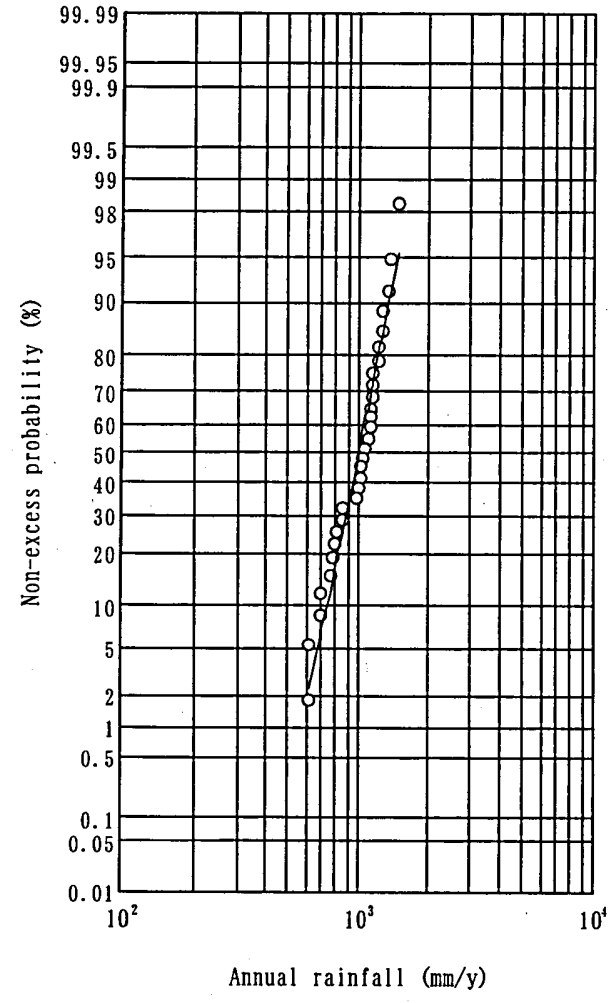

Fig. 1. (a) Non-excess probability distribution of annual rainfall observed in Sam Chuk

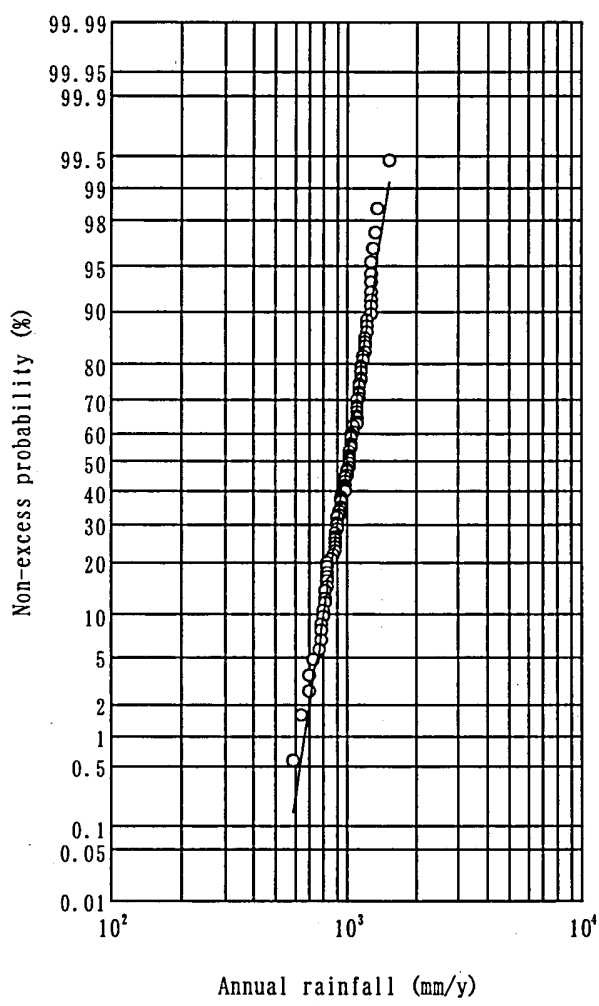

Fig. 1. (b) Non-excess probability distribution of annual rainfall generated in Sam Chuk 
observed in Sam Chuk. The probability distribution of the observed rainfall shows the reverse S-shape curve a little. We analyzed water shortage years in recent years using Fig. 1(a). The probability of water shortage in 1991 was a return period of 50 years; in 1986 it was 20 years; in 1992 it was 12 years; and in 1985 it was 8 years..

Fig. 1(b) shows non-excess probability distribution of annual rainfall by the simulated generation in Sam Chuk. Though it becomes a distribution of which the gradient is bigger than observation data a little, it is a considerably beautiful distribution. According to Fig. 1(b), the annual rainfall in ordinary year (return period of 2 years) is $1000 \mathrm{~mm} / \mathrm{y}$; 10 years is $798 \mathrm{~mm} / \mathrm{y}$; and 30 years is $724 \mathrm{~mm} / \mathrm{y}$.

Fig. 2(a) shows non-excess probability distribution of annual rainfall for 40 years observed in Ban Phraek. The probability distribution of the observed rainfall shows the tendency in which the data of dry year and wet year separate from the curve a little. We analyzed water shortage years in recent years using Fig. 2(a). The probability of water shortage in 1991 was a return period of 100 years; in 1986 it was 25 years; in 1992 it was 15 years and in 1985 it was 10 years. The rainfall in Ban Phraek is more frequent a little

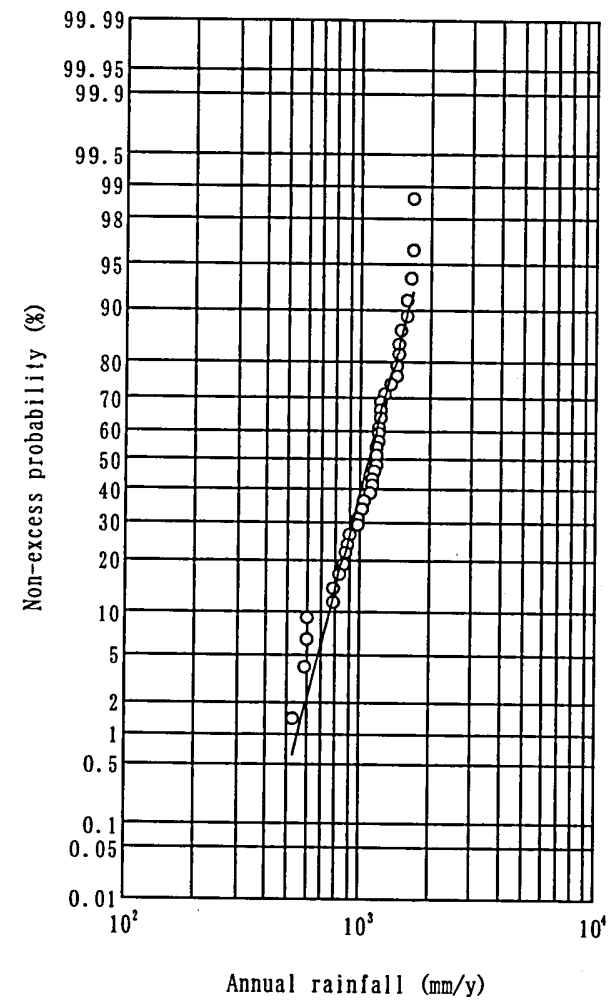

Fig. 2. (a) Non-excess probability distribution of annual rainfall observed in Ban Phraek

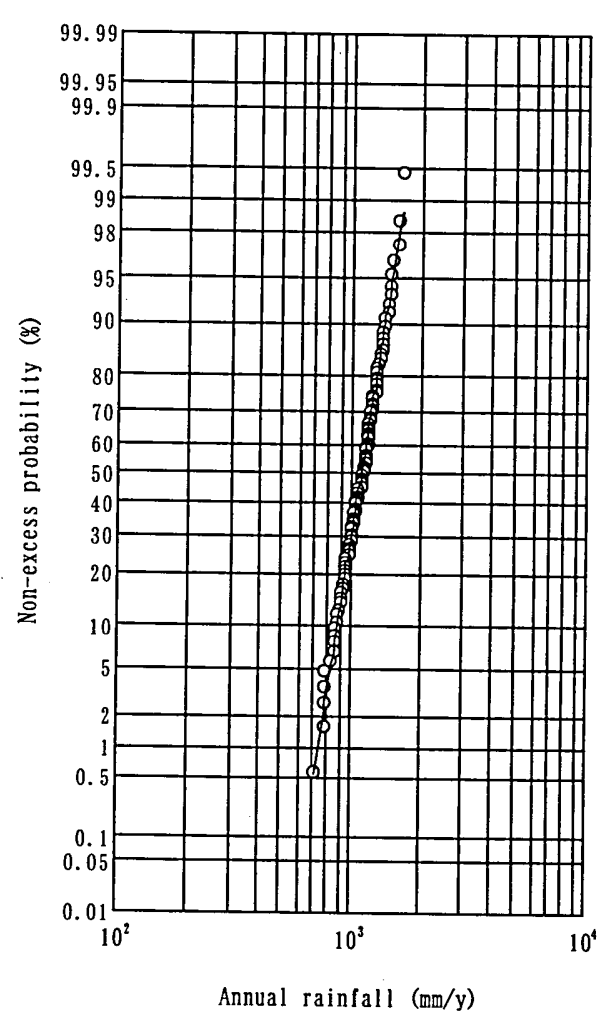

Fig. 2. (b) Non-excess probability distribution of annual rainfall generated in Ban Phraek 
than the rainfall in Sam Chuk.

Fig. 2(b) shows non-excess probability distribution of annual rainfall by the simulated generation in Ban Phraek. As well as Sam Chuk, though it becomes a distribution of which the gradient is bigger than observation data a little, it is a considerably beautiful distribution. According to Fig. 2(b), the annual rainfall in ordinary year (return period of 2 years) is $1100 \mathrm{~mm} / \mathrm{y}$; 10 years is $879 \mathrm{~mm} / \mathrm{y}$; and 30 years is $798 \mathrm{~mm} / \mathrm{y}$.

\section{WATER DEMAND PREDICTION BY GENERATED RAINFALL}

\section{Chainat-Pasak Canal area}

We tried to predict water demand using generated rainfall data of a return period of 2 years and 30 years in the $21 \mathrm{R}$ canal area. The results area shown in Fig. 3(a), Fig. 3(b),
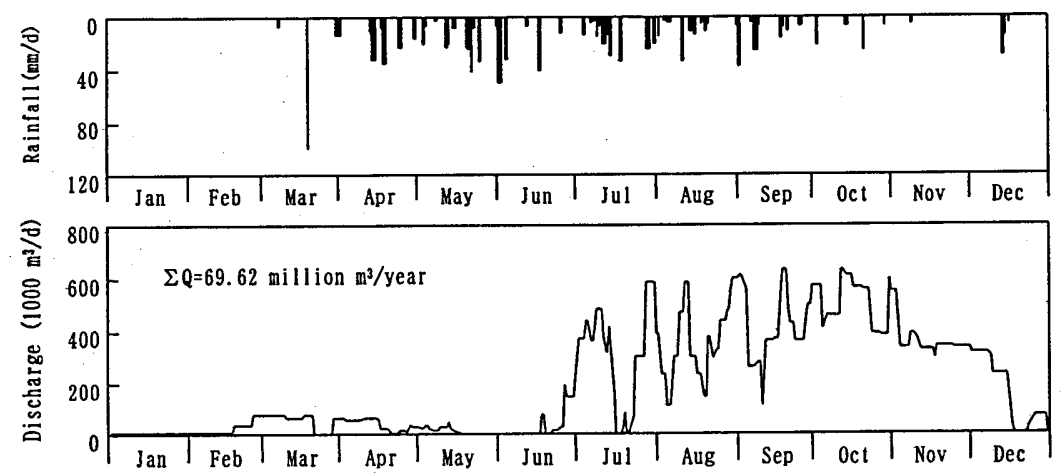

Fig. 3. (a) Water demand prediction by the simulated generation rainfall (21R in Chainat-Pasak canal, Return period 2 years, Sample 1)

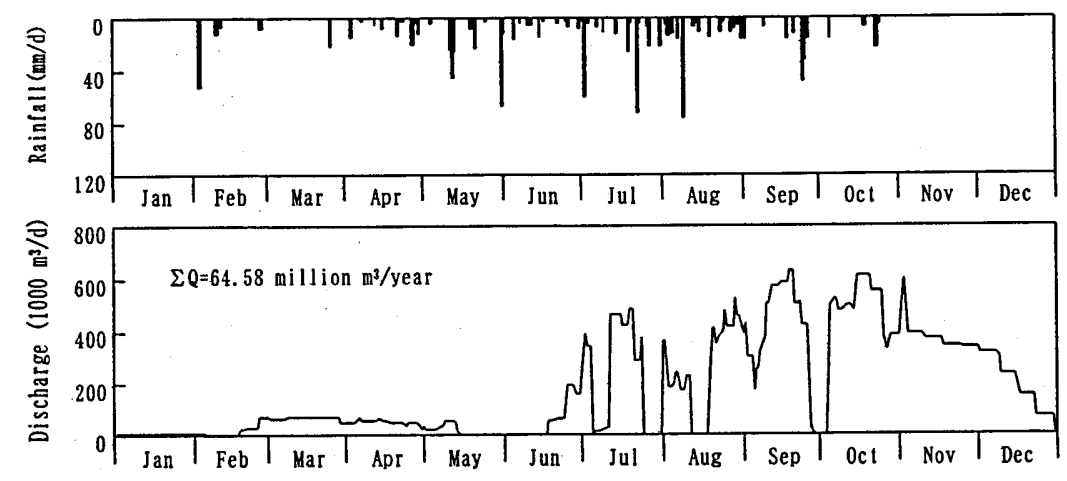

Fig. 3. (b) Water demand prediction by the simulated generation rainfall (21R in Chainat-Pasak canal, Return period 2 years, Sample 2) 

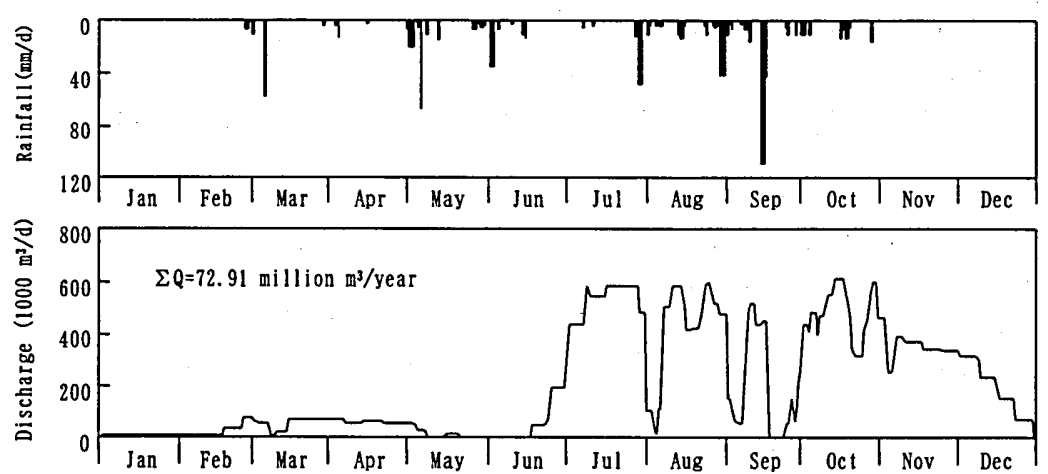

Fig. 4. (a) Water demand prediction by the simulated generation rainfall $(21 \mathrm{R}$ in Chainat-Pasak canal, Return period 30 years, Sample 1)

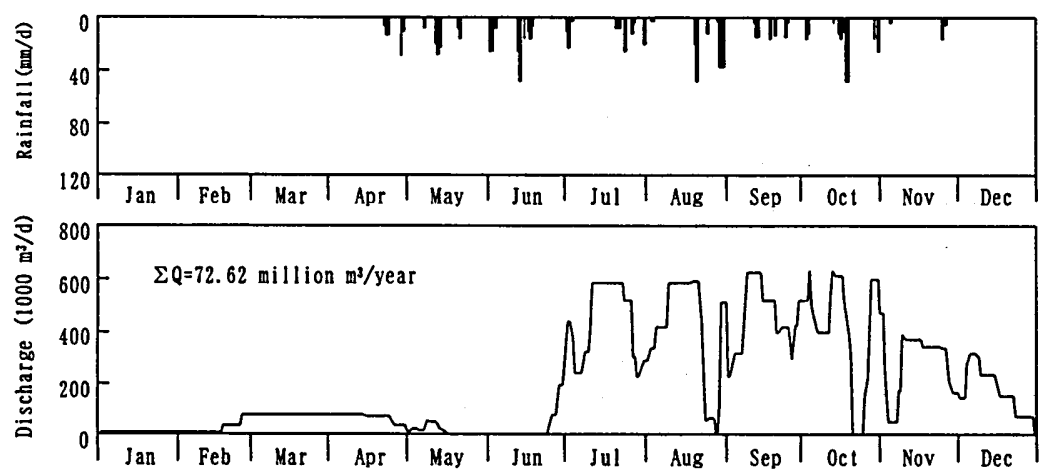

Fig. 4. (b) Water demand prediction by the simulated generation rainfall (21R in Chainat-Pasak canal, Return period 30 years, Sample 2)

Table 2. Annual water demand prediction by generated rainfall (21R in Chainat-Pasak Canal)

\begin{tabular}{cc}
\hline $\begin{array}{c}\text { Return Period } \\
\text { (year) }\end{array}$ & $\begin{array}{c}\text { Annual water demand } \\
\left(10^{6} \mathrm{~m}^{3} / \text { year }\right)\end{array}$ \\
\hline 2 (Sample 1) & 69.62 \\
2 (Sample 2) & 64.58 \\
30 (Sample 1) & 72.91 \\
30 (Sample 2) & 72.62 \\
\hline
\end{tabular}


Fig. 4(a) and Fig. 4(b). Annual water demand in each case shows in Table 2. According to Table 2, there is no the great difference in ordinary year and drought year, and water demand is expected to be about 70 million $\mathrm{m}^{3}$ even in either year in this area. In this area the rice paddy in rainy season is main crop, and there is a little planting area in dry season.

Still, it becomes about $440 \mathrm{~mm} / \mathrm{y}$, when a water demand of 70 million $\mathrm{m}^{3}$ in a year is converted into water depth, as irrigation area of this area (command area of 21R) is 15,824 ha. Since water requirement rate of the paddy rice is $11 \mathrm{~mm} / \mathrm{d}$, this is equivalent to 40 days' water demand. Therefore, about $1 / 2$ to $2 / 3$ of the irrigation water is shared by effective rainfall, when irrigation period of paddy field is 90 to 120 days.

\section{Sam Chuk area}

Planting area in the dry season was made to fluctuate at the $70 \% \sim 30 \%$ of planting area in the rainy season in Sam Chuk area, and prediction of water demand was tried

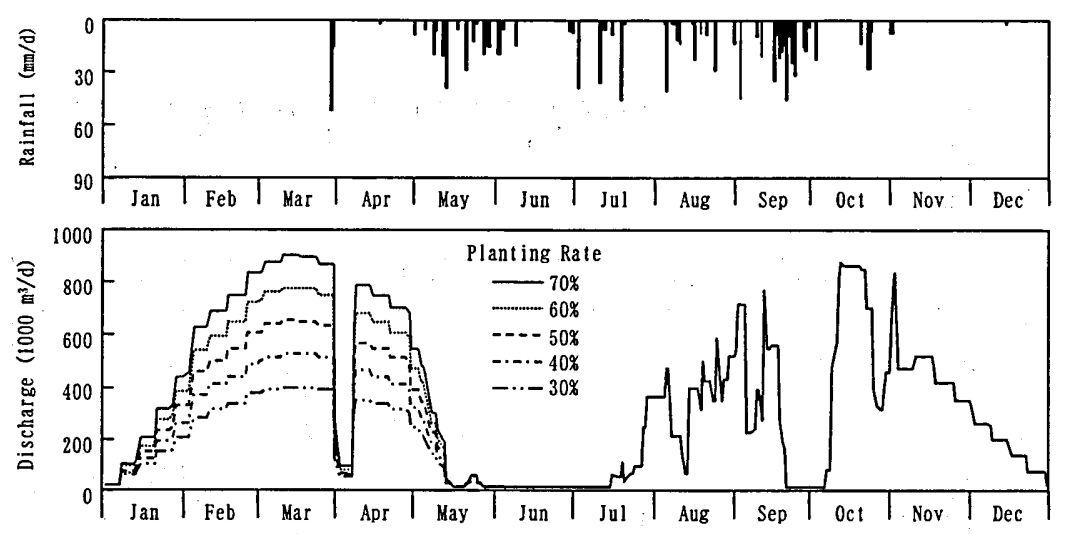

Fig. 5. Water demand prediction with planting area change in the dry season ( $1 \mathrm{R}$ in Sam Chuk Project, Return period 2 yeas, Sample 1)

Table 3. Annual water demand prediction with planting area changing in the dry season (Return period 2 years, Sample 1)

\begin{tabular}{lccc}
\hline Lines & $\begin{array}{c}\text { Planted rate } \\
\text { in dry season } \\
(\%)\end{array}$ & $\begin{array}{c}\text { Annual water demand } \\
\left(10^{6} \mathrm{~m}^{3} / \text { year }\right)\end{array}$ & $\begin{array}{c}\text { Water demand } \\
\text { in dry season } \\
\left(10^{6} \mathrm{~m}^{3} / \mathrm{season}\right)\end{array}$ \\
\hline $1 \mathrm{R} 70$ & 70 & 133.85 & 76.07 \\
$1 \mathrm{R} 60$ & 60 & 123.59 & 65.81 \\
$1 \mathrm{R} 50$ & 50 & 113.32 & 55.54 \\
$1 \mathrm{R} 40$ & 40 & 103.06 & 45.28 \\
$1 \mathrm{R} 30$ & 30 & 92.79 & 35.02 \\
\hline
\end{tabular}



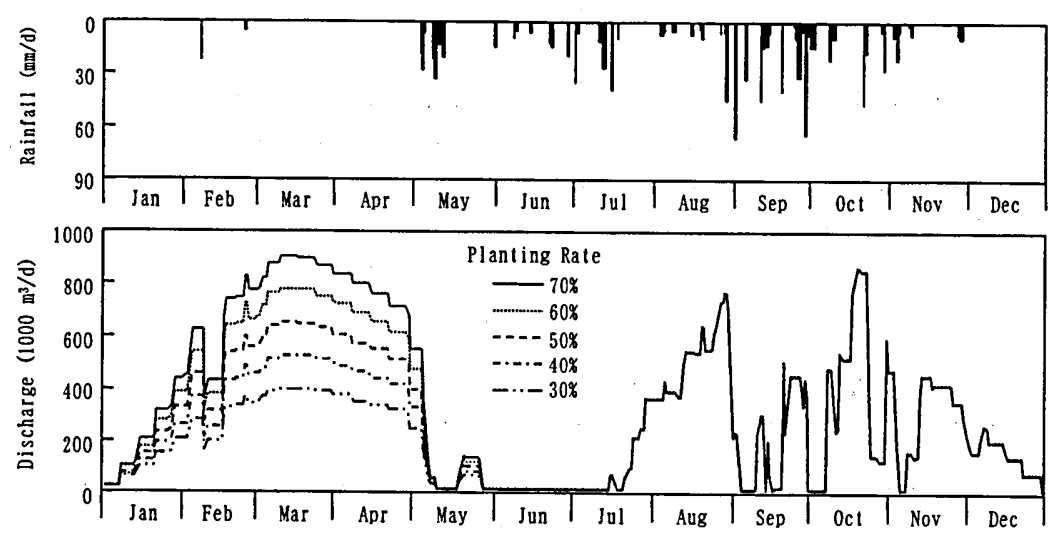

Fig. 6. Water demand prediction with planting area change in the dry season $(1 R$ in Sam Chuk Project, Return period 2 yeas, Sample 2)

Table 4. Aninual water demand prediction with planting area changing in the dry season (Return period 2 years, Sample 2)

\begin{tabular}{cccc}
\hline Lines & $\begin{array}{c}\text { Planted rate } \\
\text { in dry season } \\
(\%)\end{array}$ & $\begin{array}{c}\text { Annual water demand } \\
\left(10^{6} \mathrm{~m}^{3} / \text { year }\right)\end{array}$ & $\begin{array}{c}\text { Water demand } \\
\text { in dry season } \\
\left(10^{6} \mathrm{~m}^{3} / \text { season }\right)\end{array}$ \\
\hline 1R70 & 70 & 129.12 & 78.36 \\
1R60 & 60 & 118.61 & 67.78 \\
1R50 & 50 & 108.02 & 57.19 \\
1R40 & 40 & 97.44 & 46.61 \\
1R30 & 30 & 86.85 & 36.02 \\
\hline
\end{tabular}

using the generated rainfall for return period 2 years on each case. Still, the object area is command area of $1 \mathrm{R}$ canal.

The results are shown in Fig. 5 and Fig. 6. Annual water demand is shown in Table 3 and Table 4 on each case. In this area, according to these tables, water demand of about 50 million $\mathrm{m}^{3}$ is expected in rainy season of ordinary year. And, in case where dry paddy is planted in $30 \%$ of the planting area in rainy season, simulated water demand is about 40 million $\mathrm{m}^{3}$. In the case of $70 \%$, it is about 80 million $\mathrm{m}^{3}$.

Still, it becomes about $360 \mathrm{~mm} / \mathrm{y}$, when a water demand of 50 million $\mathrm{m}^{3}$ in a year is converted into water depth, as irrigation area of this area (command area of $1 \mathrm{R}$ ) is 14,192 ha. Since water requirement rate of the paddy rice is $11 \mathrm{~mm} / \mathrm{d}$, this is equivalent to 33 days' water demand. Therefore, about $2 / 3$ to $3 / 4$ of the irrigation water is shared by effective rainfall, when irrigation period of paddy field is 90 to 120 days.

Since 40 million $\mathrm{m}^{3}$ is about $940 \mathrm{~mm} / \mathrm{y}$ in the water depth conversion at $30 \%$ planting area in the dry season, we realize that effective rainfall can not be almost expected in the dry season. 


\section{CONCLUSION}

By the simulated generation rainfall, water demand prediction of various probability years was carried out. The result showed that most of water requirement was covered by rainfall in rainy season, but effective rainfall could not expect in the dry season almost. And it was clarified that there was seldom a difference in water demand by return period.

\section{REFERENCES}

Akira Ishikawa 1992 The Novel Development of Field Irrigation. In "Irrigation Scheduling and Water Requirement", by M. Kuroda and Y. Nakano, Agricultural Upland Development Association, Japan, pp. 184-214

Testuro Fukuda 2005 Estimation model of water requirement in farmland-Referring to the Thailand gravity irrigation district (1)-, J. Fac. Agr., Kyushu Univ., 50(2) (in press)

Testuro Fukuda 2005 Actual Water Consumption and Water Management in Paddy Field-Referring to the Thailand gravity irrigation district (2)-, J. Fac. Agr., Kyushu Univ., 50(2) (in press)

Testuro Fukuda 2005 Estimation of Water Requirement for Each Area and Actual Water Allocation-Referring to the Thailand gravity irrigation district (3)-, J. Fac. Agr., Kyushu Univ., $\mathbf{5 0}(2)$ (in press)

Testuro Fukuda 2005 Construction of Water Demand Prediction Model-Referring to the Thailand gravity irrigation district (4)-, J. Fac. Agr., Kyushu Univ., 50(2) (in press)

Testuro Fukuda 2005 Water Demand Prediction Model Used for General Purpose-Referring to the Thailand gravity irrigation district (5)-, J. Fac. Agr., Kyushu Univ., 50(2) (in press) 